\title{
God's household and the poor in contextual ecclesiology
}

C J A Vos

Dean: Faculty of Theology

University of Pretoria

\begin{abstract}
As a consequence of the bipolar tension between theory and practice, experience (considered in the South African context) influences the church's reflection on Practical Theology. Insight into the economic system of the Mediterranean world helps us to understand the complexities involved in positioning poverty, as well as the role of the New Testament faith community in its interaction with the poor. The social system in the ancient world, within which poverty was encountered, cautions us against taking a simplistic view of the poor. We cannot duplicate social systems and impose them on current situations. The New Testament, which is set against a particular system, speaks of the Kingdom of God as a place where the poor must be cared for. The New Testament (especially the Gospel of John) lets us understand that a church, which has a family orientation as its basis, should provide a home for the poor.
\end{abstract}

\section{ORIENTATION}

Practical Theology as a theory of action - an empirically oriented theological theory will be able to mediate the Christian faith in the praxis of modern society (Heitink 1996:6). Hermeneutical meditation in the field of Practical Theology has led to the realisation that the message should be sought in interaction with the context (cf Van der Ven 1990; Browning 1991; Pieterse 1993; Vos 1996; Heitink 1999). The context prompts the reader or hearer to ask certain questions of the text, which help to determine how it will be interpreted (De Wit 1991). This method of theologising implies the full 
recognition of theology's contextuality and its embeddedness in the various domains of human culture.

\section{AN ECCLESIOLOGY FROM OUTSIDE}

An ecclesiology from outside takes account of the effects of the theological nature of the church on the empirical environment. An ecclesiology, which is serious about taking account of the context and the experience of the poor, must make service and care a priority. The contextual nature of the church obliges the church to investigate and define its relationship with society. This goes hand in hand with " a radical awareness of our social and communal embeddedness" (Van Huyssteen 1999:146). It is the view from outside which leads the church to greater self-understanding.

\section{POVERTY IN SOCIETY}

Poverty can no longer be suppressed or concealed. The oppressive system of apartheid, or a new democracy, can no longer be advanced as an excuse for poverty. Poverty can no longer be regarded as the government's sole responsibility either. Society is aware of the problem and has a responsibility for dealing with it. This applies especially to the churches.

Poverty is a complex problem with numerous pitfalls. A uniform model, which is simplistically imposed on a country, would fail to get to grips with the problem. A lifestyle modelled on Western culture runs the risk of interpreting poverty primarily from a Western perspective. To avoid this danger, poverty must be tackled as a complex cultural and social reality. Poverty cannot be seen simply as a matter of cause and effect: human existence is too complex.

Traditional African culture embodies the idea of a cosmic order, a natural rhythm and balance. When disorder threatens, order is restored by means of religious rites and rituals. In this way life is preserved and prosperity regained (Soyinka 1976:2-3). Before the arrival of the Europeans the African world was whole, "a well-integrated one, with dignity and honour" (Awoonor 1976:252-254). In spite of contradictions and difficulties "the search goes on inexorably for that fundamental harmony on which their cosmic destiny rests." It is this "pristine integrity" which has been "traumatically shattered ... 
(by) the tragic encounter between Africa and Europe (Awoonor 1976:252-254). The only means of human progress, according to Awoonor, would be to reunite all things, old and new, in that pristine unity. This can be done by making the circle, the symbol of unity, bigger - to accommodate the new without abandoning the old.

Traditional Western culture has its own idea of a cosmic order. This order can be studied and expressed in the scientific formulas of cosmic laws. People search for knowledge in order to control nature and so create, by technological means, a better and bigger world. It is characteristic of this culture that it attempts to fit all things - education, leisure, religion, politics, art and nature - into its own pattern and to utilise and promote its own goal of progress and growth (cf Goudzwaard 1978; Van Aarde 1996:949).

Nature has its own intricate patterns, and any human effort to disregard nature may find that it has created an unsustainable system. Ecology may well prove to be stronger than any culture, eventually. A new awareness of the environment has taken root everywhere in the world. This awareness takes a different form in Africa, however. Westerners are largely out to tame nature, to control or even manipulate it. In African culture nature remains a mystery, a spiritual force.

In the South African experiential world plurality is a given. In a pluralised society people experience the accompanying fragmentation of personal identity, the loss of identity and the diffusion of meaning. In the light of this the different worldviews should not simply be counterpoised, because infiltration across boundaries has taken place and will continue to take place. The different perspectives on reality help us to understand and experience interaction in South Africa. The challenge and opportunity afforded by plurality also permit us to appreciate all the colours of the rainbow. Cultural plurality need not be exclusive, but could also create a space for all the various groups in South Africa. The collapse of any ideology is related to the practice of this reservation: the suspension and postponement of every exclusive choice and any final judgment in the scientific and intellectual or the aesthetic and moral areas (Ijsseling 1998:57). Postmodern intellectuals have a high regard for competence, not for universal values such as truth or freedom (Said 1994:13-14; Van Huyssteen 1999:43). In the words of the poet Heath-Stubbs (1999:66): 
As the traditional certainties melted away;

Faith had to make its tremendous leap in the dark.

In the South African context the dawn of the twenty-first century should be accompanied by ideological modesty. The grandiose story of Apartheid has failed dismally. There is no single comprehensive system that can explain the whole of reality. All our statements are tentative, especially the judgements and prejudices of various communities regarding each other.

It is clear that the world's economic system is no longer serving mankind but is instead causing poverty and destroying the biosphere. The increase in the growth in the gross domestic product (GDP) in African countries since the beginning of the nineties does not compare with the creation of permanent, safe job opportunities for both skilled and unskilled workers (Le Pere 2000:10). The number of qualified people who are unable to obtain employment is increasing annually. In the black communities people speak of "jobless graduates". Furthermore, the growth in the gross domestic product has outstripped the growth in democracy and is probably contributing to the degradation of the environment. Besides, the wealthy members of society (Le Pere 2000:10) skim off most of the benefits that accrue from this growth.

According to the labour consultants Levy and Associates, formal employment in South Africa was reduced by 100000 jobs in 1998. At the same time 400000 new jobseekers entered the labour market, and about 80000 died in 1998 (mainly from Aidsrelated diseases). This means that the country acquired an additional 420000 jobless people. It is estimated that 1 million jobs have been shed over the past ten years (De Lange 2002:2).

One of the biggest problems in South Africa is that of poverty and increasing impoverishment. Breytenbach (1998:70) concluded that people would simply have to learn to live without means, but that is easier said than done. The majority of people have become poorer during the past few decades. The truly impoverished are also increasing on a daily basis. The rich are also increasing in number (but becoming more fearful) (Breytenbach 1996:4). The following table provides evidence of these facts: (Percentage change in income of black and white income groups: 1991-1996, Whiteford and Van Sevenster 1999:20). 


$\begin{array}{lrrrrr} & \text { Poorest } & & & & \text { Richest } \\ & 40 \% & 41-60 \% & 60-80 \% & 81-90 \% & 10 \% \\ \text { Black } & -21 \% & -4 \% & 4 \% & 10 \% & 17 \% \\ \text { White } & -16 \% & -13 \% & -13 \% & -9 \% & 0 \%\end{array}$

The following conclusions can be drawn from these statistics:

- The group that showed the biggest rise in income is the top $20 \%$ of the black community.

- The HIV/Aids epidemic will have the biggest impact on the poor, because they are exposed to the virus the most, and have the fewest resources to fall back on. According to Prega Ramsamy, the acting executive secretary of the Southern African Development Community (SADC), HIV/Aids is worse among women than among men in Africa. As a result of certain biological factors and bleeding, women are more readily infected than men. Furthermore, women in Africa do not have the right to refuse sex and therefore they are more easily exposed to the virus (Beeld, 28 December 2000:13).

- Poverty has been worsening for at least three decades, and the situation cannot be expected to improve in the short term.

- The improvement of the present education system will benefit the wealthy, not the poor - except perhaps indirectly, if the wealthy provide services and taxes that could benefit the poor.

- The poor need a new kind of training, which will enable them to create work for themselves.

- This new kind of training would have to be developed and tested in practice. It would have to fit in with the social and cultural patterns of the poor community and it would have to be market-oriented.

Poverty cannot be viewed in isolation from a country's unique composition and problems. South Africa's high population growth rate - from 5 million in 1900 to 42 million in 1999 - contributes to the problem of unemployment and poverty. The high 
incidence of HIV/Aids and other illnesses such as malaria and cholera also contributes to poverty. The following table provides an insight in the destructive effects of the HIV/AIDS epidemic (Merson 2001):

\begin{tabular}{|l|l|l|}
\hline & $\begin{array}{l}\text { Estimated adult and child deaths } \\
\text { due to HIV/AIDS from the } \\
\text { beginning of the epidemic to end } \\
1999\end{array}$ & $\begin{array}{l}\text { Adults and children } \\
\text { estimated to be living } \\
\text { with HIV/AIDS as of } \\
\text { end 2000 }\end{array}$ \\
\hline North America & 470000 & 920000 \\
\hline Caribbean & 210000 & 390000 \\
\hline Latin America & 460000 & 1.4 million \\
\hline Westerr. Europe & 210000 & 540000 \\
\hline $\begin{array}{l}\text { North Africa \& } \\
\text { Mid East }\end{array}$ & 70000 & 400000 \\
\hline Sub Saharan Africa & 14.8 million & 25.3 million \\
\hline $\begin{array}{l}\text { Eastern Europe \& } \\
\text { Central Asia }\end{array}$ & 21000 & 700000 \\
\hline $\begin{array}{l}\text { South \& South-East } \\
\text { Asia }\end{array}$ & 2.6 million & 5,8 million \\
\hline East Asia \& Pacific & 52000 & 640000 \\
\hline $\begin{array}{l}\text { Australia \& New } \\
\text { Zealand }\end{array}$ & 6600 & 15000 \\
\hline TOTAL & $\mathbf{1 8 . 8}$ million & $\mathbf{3 6 . 1}$ million \\
\hline
\end{tabular}

The geographical composition of the population also has an influence on the incidence of poverty. Rural poverty is the most pervasive.

The income and consumption levels of some $60 \%$ of the rural population in subSaharan Africa fall below nationally defined poverty lines. Rapid urbanisation, which is now approaching $10 \%$ of the population, has been accompanied by spiralling growth in urban poverty. Indeed, the appalling conditions of the urban poor present a depressing spectacle in most African cities. 
In general, the burden of poverty is most severe among women, and femaleheaded households Moreover, the poverty of women has direct implications for poverty in African families. About a third of African households are estimated to be headed by women. It is further estimated that the proportion of women living in absolute poverty rose by $50 \%$ over the past twenty years as against $30 \%$ for men over the same period.

Statistics South Africa (SSA) gives the following distribution of people living on R800 or less per month: Free State - 48\%; Eastern Cape - 48\%; Northern Province $38 \%$; Northwest - 37\%; the Northern Cape - 26\%; KwaZulu-Natal - 25\%; Mpumalanga $-25 \%$; Gauteng $-12 \%$ and the Western Cape $-12 \%$. These figures reflect the numbers of people who are living below the bread line. At the national level the indices tell a tale of appalling poverty. In all, $12 \%$ of South African households have no toilet facilities, more than half the country's households have no taps in the house, almost half the country's households live in houses with three or fewer rooms and a third of the households live in squatter huts (Rapport, 2000:15).

The appalling plight of the poor sounds an urgent appeal to theology, the church and society.

\section{THE CHURCH AND THE POOR - A THEOLOGICAL PRO- FILE}

\subsection{The church as an open community}

An ecclesiology, which takes the context into account and is there for the benefit of the people (in the context) is an open church (Heitink 2000:270-274). A key term in the open church model is hospitality. Hospitality refers to the love of strangers (philoxenia, Hebr 13:2; Heitink 2000:274). Hospitality includes tending towards others, attentive intention, intentional attention, yes to the other (Derrida 1999:22). An open church is a church in the service of God's kingdom, which takes part in the discussion of values and norms, medical-ethical matters, establishment of a just society, and the problems of violence and poverty. The church also becomes a refuge where courage can be engendered and hope instilled in many, including the poor. 


\subsection{The economy of the Mediterranean world}

Insight into the economy of the Mediterranean world helps us to understand the place of poverty and the role of the New Testament community of faith. Bruce Malina (2001:97111) made some very illuminating comments on these questions. According to Malina (2001:104), three cultural norms can shed light on our understanding of the economy in the Mediterranean world:

\subsubsection{All goods are limited}

A good life is not unlimited. This implies that everything of value in life can be increased only at the expense of others. The reason for this assessment is that in the firstcentury Mediterranean world, just as in nearly all peasant societies, all goods were believed to be limited (Malina 2001:104).

This item of information from cultural anthropology serves to explain why the wealthy are believed to be wicked. Their control over more actual wealth than others is due to their own or their ancestors' taking advantage of others (Malina 2001:105). The concept of institutionalised envy occurs for example in Deuteronomy 15:9; 28:54,, 56. In the New Testament, even Jesus refers to this social reality more than once: Matthew 6:2223; 20:1-15; Luke 11:34-36 (Malina 2001:105).

\subsubsection{No one goes without necessities}

The Sermon on the Mount (Mt 6:25-32), which deals with the cares of life, indicates, among others, that the things needed for human subsistence are at hand (Schnackenburg 1985:70-71; Lambrecht 1993:302-304). In line with the picture painted in Matthew $(6: 25-32)$, it was a truism that at that time and in that cultural area that: "No person is destitute when it comes to the necessities of life, nor is any person overlooked" (cf Seneca, Epistles 17,9). The recognised exception in antiquity was the times when everyone lacked basic necessities owing to drought, famine or war. At such times money is of no value. From this it follows that money is not true wealth (Malina 2001:105-106). This view is contrary to the lifestyle of our Western world. 


\subsubsection{The rich person is inherently evil}

- Inherited wealth is stolen wealth

It seems that a common perception in the ancient Mediterranean about the wealthy was that "Every rich man is either unjust or the heir of an unjust person". This was the vulgata sententia (popular opinion) of the day (cf St Jerome, In Hieremiam, II, V,2, CCL 74:61). If all goods are limited, and people are created on a more or less equal footing, then those who have more must have taken goods from those who have less - or their ancestors did. Given that goods were limited, it was quite normal to be envious of the wealthy (Malina 2001:106-107).

- $\quad$ The amassing of wealth from avarice

Wealth is meant to meet the needs of human living. It is to be used with contentment and satisfaction (Malina 2000:107). What characterises all the wealthy is their lack of contentment, of satisfaction - and this at the expense of others. Cultural criteria of the day had the word "poor" pointing to the socially impotent and bereft, while the labels "rich" or "wealthy" were attached to the greedy and avaricious (Malina 2001:110).

- $\quad$ The purpose of wealth

Given the model of the four basic institutions (kinship, economics, politics and religion), economics in Mediterranean antiquity was embedded in kinship or in politics and was not a freestanding adaptive institution. The Roman Empire structurally resembled the applied Marxism of the People's Republic of China (or the former Soviet Union), while the rest of the Mediterranean area was structurally much like the Latin American rural areas, with large tracts of land owned by patronal families and served by client villagers (Malina 2001:103). These are embedded economies. The term "embedded economies" means that economic goals, roles, production, hiring, firing, and planning are determined by kinship and political considerations, either solely or primarily, and not purely or primarily on the basis of economic considerations (Hollenbach 1987; Malina 2001:103-104). 
True wealth, that deriving ultimately from the domestic economy, was meant to maintain human beings in adequate contentment. People were to be satisfied with having their needs met, even in noble style (Neyrey 1998:122-123, 178; Malina 2001:109). This was autarkeia (cf 2 Cor 9:8; Phil 4:11; 1 Tm 6:6; the independence of 1 Th 4:12).

Wealth was simply another means of acquiring and maintaining honour. Poverty refers to the inadequacy of life without honour, with the consequent social and personal inability to participate in the activities of the community, the inability to maintain selfrespect as defined by community social standards (Malina 2001:109-110). But owing to the avarice and hoarding of the wealthy, the poor were deprived of the honour due to them. This is an especially acute problem for Jesus and his proclamation of the restoration of Israel (Malina 2001:110). Jesus's injunction to give one's goods to the poor is not about self-impoverishment, but about redistribution of wealth; and motives for giving to the poor are not rooted in self-satisfying charity, but in God-ordained, socially required restitution (cf Lk 4:17-21; Lv 25:11-12; Malina 2001:110-111).

In Old Testament times it was not permissible to forget about the poor and the socially marginalised (Dt 15:15;24:18). The aliens, the fatherless and the widows were permitted to garner what remained of the crop of sheaves, olives and bunches of grapes (Dt 24:19-22). And remember, to love the alien is to imitate the love shown by God. Because God "loves the alien ..." (Dt 10:18) (Braulik 1998:4-5). What Deuteronomy enjoins us to do and what Jesus wants is the same thing: to love the poor.

The themes of "poverty" and "the poor" in an economic sense were not focal in New Testament times or in the New Testament. Instead, the proclamation of the Kingdom of God was a central motive in the New Testament. In the Old Testament the present and future sovereignty of God also serves as a motive for reaching out to the poor. Ulrich Berges (1999) pointed out that the socially disadvantaged person who had to struggle daily against the loss of his freedom and honour was regarded, in the proclamation in the book of Isaiah, as the favourite of Jehovah. The poor of my people (Is 10:2) become the poor, my people (Is 3:14-15). In the eschatological additions the poor are brought to Zion, there they find rest and security (Is 14:30, 32; cf Is 29:17-24; $32: 6 b-7)$. 
In the New Testament the proclamation of God's kingdom means God's control over God's own land in terms of Torah jubilee, which entailed the redistribution of wealth in Israel and restitution on the part of the wealthy Israelites. Such redistribution and restitution as part of the political economy willed by God were of primary concern, as in the Torah and the Prophets. This involves an examination of the wickedness of the rich. However, concern for the economic destitution of "the little people" is a modern construct since, by all accounts, the poor had enough for the necessities of life (Malina 2001:111).

The Jesus group members in regions with largely Israelite populations may have consisted of the destitute (ptochoi). The word ptochos refers to the "desperately poor, wretched creatures who are fighting for their survival" (Stegemann 1984:14). These poor are "social outcasts" or "disreputable" people who could not survive without charity in the social context of the New Testament experiential world (Van Aarde 1988:829-846; 1996:961). Here we can refer to the "poor" widow (Lk 21:1-4) and the "poor" beggar at the rich man's gate (Lk 16:19-21). The "poor" person acquired the social identity of a nonperson (Sarbin 1970:44). This identity of a non-person can often be ascribed to circumstance beyond the poor person's control, such as debt, exile, illness or the death of a member of the family (Van Aarde 1996:961). The word "poor" refers to more than an economic category, however. The poor were to be found among the aristocracy (Lk 6:27-32), the politically powerful (Jn 4:43-54), as well as those who belonged to the lower classes such as the landless peasant farming community (Hollenbach 1987:50-63; Van Aarde 1996:961). Such people have no one to turn to but God.

Those in communities where Israelites were a minority consisted mainly of poor day labourers and smallholders penetes, (little people) (Stegemann 1984:45). Although the penetes, (little people) had very little to live on they were "respectable" poor people (Van Aarde 1996:953).

With the rise of Jesus groups outside Palestine, the problem is no longer restitution and redistribution of wealth in Israel, but the "conversion" of the wicked wealthy. Here the wealthy are expected to share their goods with their fellow Jesus group members. This easily fits in with Hellenistic common sense views. Even for the Hellenist, the wealth derived from trading, interest taking, and any other practice aimed at 
acquiring money simply to use was inherently suspicious, if not downright perverted. Such wealth is an end, not a means to the good life (Malina 2001:110).

\section{PRELIMINARY REMARKS}

The social system within which poverty was encountered in the ancient world cautions us against taking a simplistic view of the poor. We cannot duplicate social systems and impose them on our situation. A major component of our society believes that an extra job pays off. Further, in capitalist countries people do die or suffer inordinately for lack of the necessities of life, while even fundamentalist churches have some very wealthy supporters who do not believe themselves to be vicious! The perceptions of the firstcentury Mediterranean world do not fit our contemporary values and experience; neither do the economics and social structures of antiquity (Malina 2001:104).

The New Testament, which is set against a particular social system, speaks of the Kingdom of God as a space within which the poor must be catered for. The Book of Isaiah point out that we should not see the poor as being outside God's people, but should realise that the poor are God's people. Rich and poor are equal in the sight of God. Even if the poor are scattered and humiliated in this life, their salvation lies in the fact that God lifts up the fallen and gives them a prospect of salvation in Zion. Everyone who clings to God and acknowledges God as King has his feet on the path that leads to Paradise.

The poor are more than simply an economic category. For this reason they require more than purely economic care. However, provision must be made for those who do require economic care. The way the poor are regarded and treated must change: they should be treated with humanity rather than as non-persons. The honour of the poor lies in the recognition of their humanity.

The Bible is not set in a contextless situation. We need to re-examine the context, which entails critical and creative tension between our thinking and the theological tradition.

\section{THE IMPORTANCE OF THE HOUSEHOLD}

All over Africa there is one institution that successfully takes care of all the elderly, the orphans, the handicapped, the unemployed - this institution is not the state, the church, or 
the non-governmental organisations, but the family. The household has been the centre of social, economic and religious life in African culture.

On the other hand, the disturbance of social patterns and processes in and around the household has weakened this centre and has contributed to many of the pressing problems, such as: the population explosion, sexually transmitted diseases, AIDS, violence and crime, pollution, homelessness/street children, matriarchal families, and deforestation and denudation of the land.

The community of faith can contribute in various ways to the support and building up of the family as an ecclesiastical and social system. In practice the church must help in practical ways to relieve poverty in households. The church can also fulfil her responsibility by providing pastoral care to families. Every effort must be made to make families feel at home in the community of faith. The theological concept of the church as a family must also be applied and experienced in the community of faith in every field of endeavour.

\section{THE CHURCH AS A FAMILY STRUCTURE}

The imagery built on the family springs from the fact that in ancient Mediterranean life the family was generally seen as the basic social structure (Malina 1981:94-121; Osiek \& Balch 1997). The writer uses this familiarity to convey to his readers his message of salvation and ethical conduct at the spiritual level.

The Holy Spirit makes us, the enemies of God, the friends of Jesus (Van der Watt 2000:362-367). We become more than friends. We become the family of God. In the New Testament the family imagery plays a key role, especially in John. References to ordinary family life are to be found throughout the gospels. The metaphoric dynamics based on family imagery may be described as follows (Van der Watt 2000:411). 


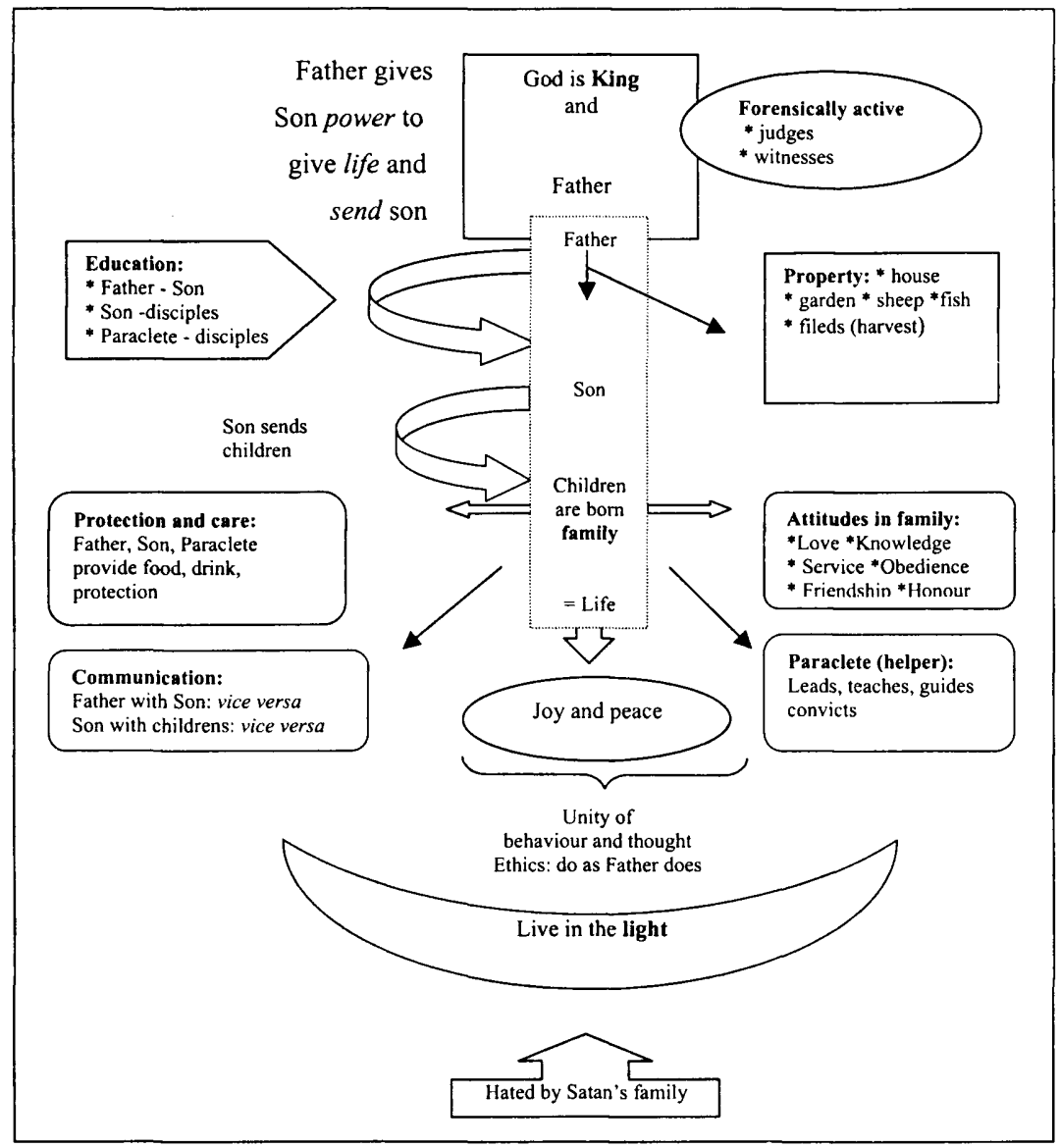

The description of family imagery given above is a description of the divine family as John sees and presents it. John seems to work with the concept known as the extended family, where not only the close inner circle (father, mother, children) are regarded as family or oikos, but also friends, slaves, workers as well as property (house, lands, animals) (Van der Watt 2000:411-413). 
This representation of the divine family provides the building blocks for an ecclesiology. The family of God is not a poor family. This is borne out by the use of term indicating property: house (1:2-3), garden (Jh 15:1-8), sheep (Jn 10), fish (Jn 21) and fields (harvest) (Jn 4:36-38) (Jn 14:2-3, 6-7; 16:15; 17:10). Instruction (or teaching) takes place in this household: Father - Son (Jn 8:29); Son - disciples (Jn 13:15; 14:15, 20-21, 23; 15:10, 12); Holy Spirit - disciples (Jn 14:26). In this household the Father, Son and Holy Spirit offer protection and care (Jn 6; 4; 6:39;10:28-29;17:11-12, 15-16; 18:9). Children born into this family (Jn $1: 12-13 ; 3: 1-8$ ) have certain obligations towards the Father and each other: love (Jn 14:16-20;3:35; 5:20;10:17-18; 17:23-26; 14:21-24; $13: 1,15 ; 14: 21,23 ; 8: 42 ; 14: 23 ; 13: 34 ; 15: 12,17 ; 15: 9 ; 14: 21 ; 17: 23 ; 15: 9-10$ ); knowledge (Jn 8:55; 10:14-15; 17:1-3), service (Jn 12:25-26), obedience (Jn14:15, 20-21; 15:10; cf Du Rand 1981), friendship (Jn 15:13-15) and honour (Jn 5:23; 7:18; 12:26). This household is characterised by communication (Jn 11:41-42; 17:1-26;14:13-14; 15:7, $16 ; 16: 23-26)$. In the household the Holy Spirit (helper) has the function of leading, teaching, reminding (Jn 14:25-26) and persuading (Jn 16:8; Du Rand 1990:26-27). The attitude to life within the family is one of joy and peace (Jn 15:10-12;17:13;16:33; $14: 25-29 ; 20: 19,21,26 ; 14: 27 f f ; 15: 11)$.

The ethic that served as the foundation for a household of this kind was doing what the Father does (Jn 5:17; 8:29,47). The creation and responsible observance of values was a focus of this ethic. Values are created with regard to both the "moral self" and the "moral society". Christian values shape the person (personal ethics), but the creation of a "moral society" (social ethics) is important as well. The "moral self" and "moral society" must be related to one another. The product of this relationship is "moral responsibility". A person is therefore responsible for his or her conduct in the household and also in society (cf Jonas 1984; Bayertz 1995; Küng 1997:27-28; De Villiers 1999; De Kruijft 1999:19-25). In a household of this kind the poor can count on protection and care, and expect love, service, friendship and honour from the other members of the family.

Within the family the role of patronatus (benefactor) offers enriching insights with regard to the poor. Man is a "reciprocal being" homo reciprocus. What is meant by this is that people do not give things away without expecting something in return (Osiek 
\& Balch 1997:49). This is especially true in primitive societies, where the exchange of gifts leads to long-term relationships between the participants, but also in modern economic transactions, where the exchange of commodities brings about a relationship between the exchanged goods (Joubert 1999:1022-1023; cf Mauss 1990). Reciprocity is a key to most forms of interaction within the Mediterranean world (Osiek \& Balch 1997:48-49).

The charitable predisposition prevailing among the ruling echelons and royalty was at the root of the early Christian ethos. In the Old East we find kings and officebearers advocating a caring attitude towards the poor and the weak (Theissen 2000:133134). In the ancient world there was a practice of giving gifts to the public (Veyne 1990). But rulers of some kind practised this: kings, aristocrats and high officials (Osiek \& Balch 1997:50). This was in fact a way of buying the loyalty of subjects (Theissen 2000:134).

This system of philanthropy led to abuses within interpersonal relationships. A person would confer certain benefits on others to put them in his or her debt until they were able to make a suitable return (Hands 1968:26-48). In De Beneficiis, a work on social philosophy, Seneca frequently refers to the abuses associated with the system of patronatus (Klauck 1996:83). He set out to persuade people to confer benefits on one another in an honourable manner, from the right motives. Seneca pointed out that the personal satisfaction that accompanies the conferring of a benefit (which should also give the recipient pleasure), should be sufficient reward for the benefactor (Seneca: I.6.1; II.31.2-4; V.20.4).

The agonistic Mediterranean culture transformed numerous kinds of social interaction into the winning of public honour (Schwankl 1997:174ff). In contrast, Seneca pointed out that the conferring of benefits should never degenerate into rivalry for honour. Philanthropic acts should never serve as an opportunity to repudiate the recipients or give prescriptive advice (Seneca II.5.6). This is why good deeds should be done in secret (Seneca II.9.1).

Paul was also aware of the various forms of reciprocity found in his time. In certain places he redefines the prevailing principles underlying reciprocity in the light of the Christ events (Phil 2:2-11; Joubert 1999:1035). In the Christian household 
philanthropy is given new content: personal honour lies in serving others. This perspective is also illustrated in Romans 15 when Paul discusses the acceptance by Jerusalem of the funds that have been collected.

Shortly before the funds that had been raised were handed over in Jerusalem, Paul says that his congregation are under an obligation to contribute to the collection ( $\mathrm{Rm}$ 15:27). In view of the numerous theological and logistic problems attached to the collection of the funds, this project which was undertaken within the Pauline communities was no mean feat (Joubert 1999:1034). It served to reaffirm Paul's status and role as apostle and philanthropist in the eyes of the communities (Joubert 1999:1034).

When it seems possible that the collection may be rejected (Rm 15:30-31), Paul redefines his role as a philanthropist. As a prospective benefactor of Jerusalem, Paul is probably on the point of gaining great public honour in Jerusalem, but he prefers to emphasise his role as diakonos (Joubert 1999:1034; 2000:208-209). His honour is subordinated to the koinonia between his congregations and Jerusalem. Paul describes the collection as a success. He emphasises the role of his congregations, who have honourably fulfilled their moral obligations towards Jerusalem (Joubert 2000:209). The collection should be regarded as a gift and not as a loan to be repaid at a later date (Joubert 1999:1034-1035). They have discharged their responsibility within the reciprocity relationship with Jerusalem, irrespective of what the latter's response may be (Joubert 2000:210). Even the small contributions they made enabled the congregations to see themselves as benefactors, participating in the giving of gifts across national boundaries, as only kings and aristocrats were sometimes able to do (Theissen 2000:141).

It was probably in the time of Tertullianus that philanthropy, as found in the Graeco-Roman world, was entirely replaced in Christendom by altruistic service to one's neighbour (Joubert 1999:1035). In his Apologetica (39,7), Tertullianus writes that, instead of becoming involved in typical reciprocal relationships and acting in accordance with the rules that have been laid down, Christians prefer to give to the poor, the orphans and the elderly, who cannot reciprocate (cf Veyne 1990).

God's family is bound together by the Christ events. "Although he was rich, for your sake he became poor, so that through his poverty you might become rich" ( 2 Cor 8:9). Our natural tendencies as homo reciprocus is to give in order to receive: to place 
others under a moral obligation towards us, and in our debt. This enables us to buy honour. But in God's family the order is reversed. Because the Son has made us rich, we give to the poor. Because God chose those who are poor in the eyes of the world to be rich in faith and to inherit his kingdom ( $\mathrm{Ja} 2: 5$ ). To the communities of faith, helping to build God's kingdom means playing the part of benefactors through the function of diakonoi, with a view to koinonia.

It is more blessed to give than to receive (Ac 20:35). This proverb, which is not found in the Gospels, was a general charitable principle in antiquity and has been ascribed to the Greek ruler Ptolemy (Theissen 2000:135-136). In the proverb employed by Paul the emphasis is on the care of all members of the community, who support one another (Theissen 2000:136). Because we have received we give without expecting repayment. We do not give with a view to gaining some advantage or claiming a tax rebate. We do not give money as a loan that will have to be repaid. We care for and serve one another. We owe one another, and especially the poor, the duty of care and love in the service of the Christian family. Our honour lies in fulfilling this duty. In God's family those in need have a higher status than those who provide help (Mt 25:44).

\section{A FAMILY WHICH INCLUDES THE POOR}

God's family owes one another faith, hope and love. We should all meet this obligation to the poor in our household. There is a place for the poor in God's household, where their identity changes from that of a non-person to that of a child of God. In the Father's household people live not only on grace, but also on bread. We obtain grace from the Father as a gift. We owe one another daily bread.

\section{Works consulted}

African Ministers' Report 1994. African common position on human and social development in Africa. Document presented by die Conference of African Ministers Responsible for Human Development to the Preparatory Committtee for the World Summit for Social Development, Economic Commission for Africa, Unesco, 4.

Awoonor, K 1976. The breast of the earth. New York: Anchor Books. 
Bayertz, K 1995. Herkunft der Verantwortung, in Bayertz, G (Hrsg), Verantwortung. Prinzip oder Problem? Darmstadt: Wissenschaftliche Buchgesellschaft.

Berges, U 1999. De Armen van het boek Jesaja: Een bijdrage tot die literatuurgeschiedenis van het Oude Testament. Nijmegen: Katholieke Universiteit.

Braulik, G 1998. "Conservative reform": Deuteronomy from the perspective of the sociology of knowledge. Unpublished Lecture.

Breytenbach, Breyten 1996. The memory of birds in times of revolution. Kaapstad: Human \& Rosseau.

- 1998. Aantekeninge van 'n "Middelwêreld". Fragmente 1, 24-37.

Browning, D S 1991. A fundamental Practical Theology: Descriptive and strategic proposals. Minneapolis: Fortress Press.

De Kruijft, G G 1999. Christelijke ethiek: Een inleiding met sleutelteksten. Zoetermeer: Meinema.

De Lange, J. 15 Februarie 2000. Suid-Afrika het verlede jaar 420000 werkloses bygekry. Sake Beeld, 2.

Derrida, J 1999. ADIEU to Emmanuel Levinas. Stanford: Stanford University Press.

De Villiers, D E 1999. Challenges to Christian ethics in the present South Africa. Scriptura 69, 75-91.

De Wit, J H 1991. Leerlingen van de armen. Amsterdam: VU Uitgeverij.

Du Rand, J A 1981. Entolé in die Johannesevangelie en -briewe. Pretoria: NTWSA.

- 1990. Johannese perspektiewe: Inleiding tot die Johannese-geskrifte. Pretoria: Orion.

Goudswaard, B 1987. Kapitalisme en vooruitgang. Amsterdam: Van Gorcum Assen.

Hands, A R 1968. Charities and social aid in Greece and Rome. Ithaca, NY: Cornell University Press.

Heath-Stubbs, J 1999. The sound of light. Manchester: Carcanet.

Heitink, G 1999. Practical Theology. History. Theory. Action Domains. Grand Rapids: William B Eerdmans Publishing Company.

- 2000. Het publieke karakter van de kerk. Skrif en Kerk 2, 270-276.

Hollenbach, P 1987. Defining rich and poor: Using social sciences, in Richards, $\mathrm{K} \mathrm{H}$ (ed), SBL, 1987 Seminar Papers, 50-63. Atlanta: Scholar Press.

Ijsseling, S 1998. Politeïsme en die postmoderne. Fragmente 2, 39-58. 
Jerome S sa, In Hieremiam $11, V, 2, C C L 74$.

Jonas, H 1984.The imperative of responsibility. Chicago: University of Chicago Press. Joubert, S J 1999. "Homo reciprocus": Seneka, Paulus en weldoenerskap. HTS 55(4), 1022-1038.

- 2000. Paul as Benefactor: Reciprocity, strategy and theological reflection in Paul's collection. Tübingen: Mohr Siebeck.

Klauck, H J 1996. Die religiöse Umwelt des Urchristentums 11: Herrscher- und Kaiserkult, Philosophie. Stuttgart.: Verlag W Kohlhammer.

Küng, H 1997. A global ethic in an age of globalization. Business Ethics Quarterly 1727.

Lambrecht, J 1994. Een is onze Meester: Luisteren naar het Matteüsevangelie. AltioraAverbode: Bijbelstichting Katholieke Bijbelstichting Den Bosch.

Le Pere, G. 21 November 2000. Beeld, bl 10.

Malina, B J 2001. The social gospel of Jesus: The Kingdom of God in Mediterranean perspective. Minneapolis: Fortress Press.

- 1981. The New Testament world: Insights from cultural anthropology. Atlanta: John Knox Press.

Mauss, M 1990. The gift: The form and reason for exchange in archaic societies. London: Norton.

Merson, M. 2000. Yale School of Public Health. Unpublished Lecture, 8 March 2000, University of Pretoria.

Neyrey, J H 1998. Honor and shame in the Gospel of Matthew. Louisville: John Knox Press.

Osiek, C \& Balch, D L 1997. Families in the New Testament World. Household and house churches. Louisville: John Knox Press.

Pieterse, H J C 1993. Praktiese Teologie as kommunikatiewe handelinge. Pretoria: RGN-Uitgewery.

Ramsamy, Prega 28 Desember 2000. Beeld, bl 13.

Rapport 10 September 2000, bl 15.

Said, E W 1994. Representations of the intellectual: The 1993 Reith Lectures. London: Vintage. 
Sarbin, T R 1970. The culture of poverty, social identity, and cognitive outcomes, in Allen, V L I, Psychological facotrs in poverty. New York: Academic Press.

Schnackenburg, R 1985. Matthäusevangelium, 1, 1-16, 20. Würzburg: Echter Verlag.

Seneca. De Beneficiis 1.6.1; 11.3. 1.6.1; II. 5.6; II. 9.1; II. 31.2-4; V.20.4; VI 34-35.

Seneca. Epistles 17, 9.

Soyinka, W 1976. Myth, literature and the African world. London: Cambridge University Press.

Stegemann, W 1984. The gospel of the poor, tr by Dietlinde Elliott. Philadelphia: Fortress Press.

Schwankl, O 1997. "Lauft so dass ihr gewinnt": Zur Wettkampfmetaphorik in 1 Kor'9. Biblische Zeitschrift 41(2), 174-191.

Tertullianus. Apologetica 39.7.

Theissen, G 2000. Die Religion der ersten Christen: Eine Theorie des Urchristentums. Gütersloh: Gütersloher Verlagshaus.

Van Aarde, A G 1988. Jesus en die sosiaal-veragtes. HTS 41, 829-846.

- 1996. Armoedekultuur: Die leefwêreld van die Nuwe Testament en die situasie in Suid-Afrika vandag. HTS 52, 947-964.

Van der Ven, J A 1990. Entwurf einer empirischen Theologie. Kampen: J H Kok.

Van der Watt, J G 2000. Family of the King: Dynamics of metaphor in the Gospel according to John. Leiden: Brill.

Van Huyssteen, J W 1999. The shaping of rationality: Toward interdisciplinary in theology and science. Michigan: William B Eerdmans.

Van Niekerk, A S November 1987. The reception of resistance to development: A perspective. Development Southern Africa 4:4, 625-639.

- 2000. A strategy against poverty in Africa. Unpublished report, University of Pretoria, 1-11.

Veyne, P 1990. Bread and circuses: Historical sociology and political plurism. London: Penguin Books.

Vos, C J A 1996. Die Volheid Daarvan, I: Homiletiek uit 'n hermeneuties-kommunikatiewe perspektief. Pretoria: RGN-Uitgewery.

Whiteford, A \& Van Sevenster, D E 1999. Winners and Losers: South Africa's changing income distribution in the 1990s. WEFA Southern Africa, i-iv, 1-48. 